\title{
Corrosion Behavior of X80 Steel Under Anodic Polarization
}

\author{
Su Xibeier ${ }^{1}$,Wang Wenwu ${ }^{1, *}$, Wang Lei $^{2}$, Yu Hao ${ }^{3}$ \\ ${ }^{1}$ Liaoning Shihua University College of Petroleum Engineering, Fushun, China, 113001 \\ ${ }^{2}$ No.1 Pipeline Company, China Petroleum Pipeline Engineering Co., Ltd., Langfang, China, 065000 \\ ${ }^{3}$ Petrochina Henan Gas \& Marketing Company, Zhengzhou, China, 450000 \\ *E-mail: wwenwu_pet@163.com
}

doi: $10.20964 / 2020.03 .07$

Received: 3 November 2019 / Accepted: 15 December 2019 / Published: 10 February 2020

\begin{abstract}
To investigate the corrosion behavior of X80 steel caused by an anodic current density, electrochemical tests of X80 steel in near-natural NS4 solution under varying anodic current densities, $I_{\mathrm{ac}}$, were performed. The testing combined a three-electrode and direct-current source. Analysis included electrochemical testing and corrosion morphology. The results show that the corrosion behavior of X80 steel in NS4 solution is mainly divided into two stages. The first stage, $I_{\mathrm{ac}}=0 \sim 20 \mathrm{~mA} / \mathrm{cm}^{2}$, was characterized by the formation of a double electric layer and a corrosion-product layer mainly comprised of FeOOH. During this stage uniform corrosion occurs and $I_{\text {corr }}$ increases linearly. In the second stage where $I_{\mathrm{ac}} \geq 50 \mathrm{~mA} / \mathrm{cm}^{2}$, the corrosion morphology is pitting corrosion and $I_{\text {corr }}$ is basically unchanged. Black $\mathrm{Fe}_{3} \mathrm{O}_{4}$ is the primary inner layer corrosion product that inhibits uniform corrosion and promotes pitting corrosion.
\end{abstract}

Keywords: Anodic polarization; X80 steel; Polarization curve; EIS; Corrosion morphology

\section{$\underline{\text { FULL TEXT }}$}

(C) 2020 The Authors. Published by ESG (www.electrochemsci.org). This article is an open access article distributed under the terms and conditions of the Creative Commons Attribution license (http://creativecommons.org/licenses/by/4.0/). 